\title{
IMPLICATIONS OF CJEU JURISPRUDENCE ON THE DELIMITATION OF WORKING TIME BY REST TIME IN THE COLLABORATIVE ECONOMY
}

\author{
Răzvan ANGHEL*
}

\begin{abstract}
The specificity of the collaborative economy has raised a number of issues with regard to the qualification of legal relationships between workers, final beneficiaries and the online platform that mediates the provision of work, respectively whether between the platform and the worker there is an employment relationship or there is a commercial relationship between the platform, self-employees and consumers. In particular, the question arises whether, in the case of these workers, the working time regulations apply and, if so, how they can be applied in concrete manner. The article contains an analysis on how some principles derived from the CJEU case law can be used to determine whether and under what conditions workers in the collaborative economy can benefit from protection by limiting working time and how can work time be delimited by rest time in their case, given the specificity of their work condition, in order to ensure an effective protection. ${ }^{* *}$
\end{abstract}

Keywords: working time, rest time, collaborative economy, workers, employees, self-employees.

\section{Introduction}

The development of information and communication technology has led to the emergence of new forms of work and working time arrangements, and has made it possible to increase the degree of labor flexibility, driven by economic, but also social and personal needs. The phenomenon is not very new, appearing in the early 1970s in first forms and developing along with the development of mobile communications and information technology, especially in the last 30 years, after the emergence and development of the INTERNET ${ }^{1}$.

In present time work is also done in what is called the "collaborative economy" or "the gig economy" in which the worker is essentially directly linked to the client via a platform accessible on the INTERNET ${ }^{2}$,

\footnotetext{
* PhD Candidate, Faculty of Law, University of Bucharest, email: anghel.razvan@drept.unibuc.ro; judge, president of the First Civil Section, Constanţa Court of Appeal.

** This work is a result of the research conducted by the author during the doctoral program followed within the Doctoral School of Law of the Faculty of Law of the University of Bucharest.

${ }^{1}$ See for this evolution: Jon Messenger, Luty Gschwind - Three Generations of Telework, Conference paper $17^{\text {th }}$ ILERA World Congress, 7-11.09.2015, Cape Town, South Africa, available at https://www.ilera2015.com/dynamic/full/IL156.pdf (accesed 13.03.2019).

2 See for details, for example: A. Donini, Il lavoro digitale su piattaforma, Labour \& Law issues, no. 1/2015, pp. 5071; E. Dagnino, Il lavoro nella on-demand economy: esigenze di tutela e prospettive regulatorie, Labour \& Law issues, no. 2/2015, pp. 87-106; A. Aloisi, Il lavoro ,a chiamata” e le piattafrme online della collaborative economy: nozioni e tipi in cerca di tutele, Labour \& Law issues, no. 2/2016, pp. 18-56; G. Friedman, Workers without employers: shadow corporations and the rise of the gig economy, Review of Keynesian Economics 2.2/2014, pp. 171-188; A. Aloisi, Commoditized workers: Case study research on labor law issues arising from a set of on-demand/gig economy platforms, Comp. Lab. L. \& Pol'y J. 37/2015, p. 653; J. Hamari, M. Sjöklint, A. Ukkonen, The sharing economy: Why
} 
which rises in the first place the question of whether such a worker has the status of worker or employee and, consequently, the question whether or not he/she enjoys the protection guaranteed to employees, which is still unclear in the European case-law.

It can be noticed a return to taskoriented work, to a result that must be achieved at a certain time, at least in certain areas of activity, the classic concept of working time remaining still largely applicable in the industrial field ${ }^{3}$.

The use of information technology has allowed work to be unspatialised, and the physical space of its deployment has become less relevant in this context ${ }^{4}$.

The notion of collaborative economy includes business models in which activities are facilitated by online platforms that generate an open market for the temporary use of goods or services provided by individuals ${ }^{5}$.

In the collaborative economy, work is organized in two main forms: crowdwork the creation of micro-tasks for which a global offer is launched through an on-line platform and can be done anywhere; ondemand services - performing services in a certain area, hired through an on-line application $^{6}$.

There is a difference in the organization of working time between the two forms of work arrangements. In the case of crowdwork, the worker has greater autonomy and can work at any time in principle, while in the case of on-demand work, the on-line platforms exercise greater control over the services provided by setting quality standards and limiting providers' freedom to choose tasks and customers ${ }^{7}$.

The delimitation of working time from rest time and the limitation of the first when working in the collaborative economy presents numerous difficulties, the boundary between working time and rest time being very difficult to determine, porous ${ }^{8}$, in this case, the rest time being affected by interspersed periods of activity ${ }^{9}$, and the carrying out of the activity may involve the

people participate in collaborative consumption, Journal of the Association for Information Science and Technology 67.9/2016, pp. 2047-2059; J. Schor, Debating the Sharing Economy, Journal of Self-Governance \& Management Economics 4.3/2016; B. Cohen, J. Kietzmann, Ride on! Mobility business models for the sharing economy, Organization \& Environment 27.3/2014, pp. 279-296; H. Heinrichs, Sharing economy: a potential new pathway to sustainability, GAIA-Ecological Perspectives for Science and Society 22.4/2013, pp. 228-231.

${ }^{3}$ It has been shown that the limit between working time and rest time becomes more unclear as a result of the increasing variability of the work program on the one hand and the increasing task orientated work which results in a bigger pressure to work the hours required to perform the task - J. Rubery, Working time in the UK, Transfer: European Review of Labour and Research 4.4/1998, p. 672.

${ }^{4}$ Răzvan Anghel - Noua reglementare privind telemunca. Probleme specific privind delimitarea timpului de lucru de timpul de odihnă în cazul telesalariaţilor, Curierul Judiciar, no. 4/2018, p. 211.

${ }^{5}$ Communication from the Commission to the European Parliament, the Council, the European Economic and Social Committee and the Committee of the Regions - A European agenda for the collaborative economy, Brussels, 2.6.2016 COM (2016) 356 final, available at: https://ec.europa.eu/transparency/regdoc/rep/1/2016/EN/1-2016-356EN-F1-1.PDF, p. 3, accessed on 13.03.2019.

${ }^{6}$ Jon Messenger - Working time and the future of work, International Labour Organization, ILO Future of Work Research Paper Series, 2018, p. 22; see for the evolution and the definition of crowdwork: Janine Berg, Marianne Furrer, Ellie Harmon, Uma Rani, M Six Silberman - Digital labour platforms and the future of work - Toward decent work in the online world, International Labour Organization, 2018, p. 3.

${ }^{7}$ Jon Messenger - Working time and the future of work, cited, p. 23.

${ }^{8}$ A. Supiot, Temps de travail: pour une concordance des temps, Droit social, 1995, pp. 949-950.

${ }^{9}$ J.-Y. Boulin, Working time in the new social and economic context, Transfer: European Review of Labour and Research 7.2/2001, p. 204. 
alternation of intensive work periods with inactive periods ${ }^{10}$.

It has been shown that "the normal working time pattern, which characterized Ford's standardized, industrial, mass production, loses its force," and "for much of the labor force over the last two decades, working time has become not just shorter but also more flexible and heterogeneous", being noticed that "the variable forms of working time take the place of uniform ones" 11 .

Thus, in the labour relations that were born in the mass industrialization process, there was a difference between the "paid time" for which the employee received financial compensation - the salary - and the "free time" at his disposal ${ }^{12}$. If in the conception of the industrialization era on the organization of labour, working time was a spatial time in which the collective of workers was placed in a community of place, time and action ${ }^{13}$, the new possibilities of modelling the organization of the working time and the labour offered by the information technology, have raised new problems regarding the delimitation of working time by rest time ${ }^{14}$.

Also, the subordination of the worker to the employer, which is characteristic of the traditional model of the employment relationship, has been gradually replaced in many areas by the assignment of tasks and objectives and the granting of greater autonomy to the employees, by applying flexible procedures for their coordination ${ }^{15}$, which resulted in the transfer of working time control from the employer to the employee and the increasing difficulty of delimiting working time from rest time.

In the collaborative economy, the worker's autonomy is considered to be defining although there is no solid empirical evidence in this respect ${ }^{16}$. On the contrary, it is highlighted a blurred boundary between working time and privacy time ${ }^{17}$ and lack of control over working time ${ }^{18}$.

The degree of autonomy of the worker, expressed in the possibility to choose the task to be performed, the time used for this purpose and the way of organizing and performing the work, differs significantly depending on the control exercised by the platform administrator and the type of activity ${ }^{19}$.

At the same time, the space boundaries are blurred in the sense that space for work is increasingly entering the space for private life; at the same time, it is remarked that work is space-independent ${ }^{20}$.

At the present, understanding and defining working relationships in the

\footnotetext{
${ }^{10}$ J.-Y. Boulin, G. Cette, D. Taddéi, Le temps de travail: une mutation majeure, Futuribles 5/1992, p. 8.

${ }^{11} \mathrm{H}$. Seifert, Flexibility through working time accounts: reconciling economic efficiency and individual time requirements, WSI - Diskussionspapiere, no. 130/2004, p. 1.

12 J. Rubery, K. Ward, D. Grimshaw, H. Beynon, Working time, industrial relations and the employment relationship, Time \& Society 14(1)/2005, p. 91.

${ }^{13}$ P. Bouffartigue, J. Bouteiller, A propos des normes du temps de travail, Revue de l'IRES no. 42/2003, 2. p. 8.

${ }^{14}$ Răzvan Anghel - Noua reglementare privind telemunca..., cited, p. 213.

15 C.A.Moarcăş, Impactul globalizării asupra reglementărilor din domeniul muncii. Posibile schimbări în sistemul relaţiilor industriale, Public Law Review, no.1/2005, pp. 28- 29.

${ }^{16}$ Jon Messenger - Working time and the future of work, cited, pp. 23-24.

${ }^{17}$ Jon Messenger - Working time and the future of work, cited, pp. 21, 24, 25.

${ }^{18}$ EUROFOUND - Work on demand: Recurrence, effects and challenges, Publications Office of the European Union, Luxembourg, 2018, p. 4.

19 for a classification of activities provided through on-line platforms and the way they are provided see EUROFOUND, Employment and working conditions of selected types of platform work, Publications Offices of the European Union, Luxemburg, 2018, pp. 5, 21.

${ }^{20}$ Jon Messenger - Working time and the future of work, cited, p.19.
} 
collaborative economy are deficient, although the key issue in their analysis and in the analysis of working time organization is their classification ${ }^{21}$, as it is essential to determine whether they are employment relationships or business relationships.

The work done within the framework of the collaborative economy generates problems regarding the protection of the persons carrying out such activities, including the problem of limiting the working time for the purpose of protection of health and safety at work, but also for ensuring a balance between professional life and personal life.

But in order to solve this problem, it must first be determined whether the legal rules that require working time limitation are applicable. In the next stage, in order to ensure the protection offered by these normative acts, the working time must be firstly delimited by the rest time, as it can only be limited something defined and determined; as a result, it has to be checked whether this delimitation process is possible in practice and by what methods.

The legal framework applicable in the European Union on the organization of working time is Directive 2003/88 and the sectoral directives, as well as the internal rules for transposing them. The jurisprudence of the Court of Justice of the European Union may provide benchmarks to determine whether and how these legal acts can be enforced, even if the Court has not yet expressly addressed those issues.

\section{Applicability of rules on the} organization of working time

\subsection{General aspects}

The Working Time Directives are, as a rule, applicable to workers, an autonomous concept of EU law, with the exception of Directive 2002/15 on road transport, which also applies to self-employed workers.

By reference to Article 2 (1) of Directive 89/391 / EEC, to which Article 1 (3) of Directive 2003/88 / EC refers, the latter applies to all areas of activity ${ }^{22}$. It is true that Article 2 (2) of Directive 89/391 / EEC excludes from its scope activities which have inherent characteristics which are inevitably inconsistent with the provisions of the Directive but only if they form part of the public administration so those activities in the collaborative economy that are activities in the private domain, cannot be excluded ${ }^{23}$.

In the judicial practice, more and more have raised the issue of the nature of the legal relationships established in the collaborative economy between those who provide the work and the operators of the online platforms that put the first ones in contact with the clients. The problem is generated by the fact that, viewed globally, it seems that a feature of the collaborative economy is that service providers are often individuals who occasionally offer goods or services from individual to individual, but, in the mean time collaborative platforms are increasingly used by micro-enterprises and small entrepreneurs ${ }^{24}$.

\footnotetext{
${ }^{21}$ Jon Messenger - Working time and the future of work, cited, p. 22; EUROFOUND - Work on demand.., cited, p. 3.

22 see, among many others, CJEU, Judgment of 14.10.2010, 2nd Chamber, case C-428/09, Union syndicale Solidaires Isère c. Premier ministre, Ministère du Travail, des Relations sociales, de la Famille, de la Solidarité et de la Ville, Ministère de la Santé et des Sports, ECLI: EU: C: 2010:612, par.21, 22; Judgment of 5.10.2004, Pfeiffer e.a., C-397/01-C-403/01, Rec., p. I-8835, par.52, www.curia.eu.

${ }^{23}$ As fear was expressed: Alan Bogg, Foster parents and fundamental labour rights, www.uklabourlawblog.com, 25.07.2018, par.16.

${ }^{24}$ Communication from the Commission to the European Parliament, the Council, the European Economic and Social Committee and the Committee of the Regions - A European agenda for the collaborative economy, cited, p. 5.
} 
Thus, on-line platform operators claim that it is a commercial relation, and those that do the work are self-employed, professionals that are leading their own business, while some of them who have filed a complaint with the courts claim that they are employees engaged in a labour relations.

This issue must be addressed with priority, since working time rules apply only if the person who performs the work has the status of a worker, otherwise, if it is a commercial relationship, these rules are not applicable as only workers enjoy protection by limiting working time and also benefit of guaranteed rest periods, considering the relationship of subordination with the employer, as opposed to an independent professional who is in a tie with the contractual partner.

If the person who performs the work in the collaborative economy is considered to be an independent service provider, the provisions of Directive 2006/123, which generally define service providers, or special directives such as Directive 86/653 / EEC on self - employed commercial agents, are applicable and those regulations do not provide for protection measures with regard to the organization of working time, assuming that the self - employed is free to organise the work to do. Only Directive 2002/15 also applies to self-employed workers.

It is important, however, that the attribution of the status of a worker does not depend on the classification of the legal relationships in which he/she is part according to the national law, being an autonomous notion of Union law ${ }^{25}$.
However, it is essential if there is a subordinate relationship between the on-line platform operator and the worker. The first element of this subordinate report implies that the platform operator has control over the organization of the activity.

So, in order to determine the nature of these legal relationships, two aspects need to be considered:

- if the services offered to the beneficiaries are an activity of the operator of the on-line platform or belong to the natural person providing the work and the platform acts only as an intermediary between the service provider and the beneficiary offering only the frame for the demand to meet the offer; if the on-line platform merely provides intermediation services between professionals and customers, the work done does not belong to it, but belongs to the professional so that it is excluded that the operator of the platform is considered an employer and, as a consequence, the person who provides the work to be considered a worker;

- If the activity is considered to be organized and to belong to the operator of the on-line platform, it should be analysed whether the natural persons performing the work are commercial partners, subcontractors of the operator of the platform, or have the status of employees of the platform, i.e. workers.

It is acknowledged, however, that in the context of the collaborative economy there are increasingly blurred boundaries between the category of workers employed

${ }^{25}$ CJEU (Grand Chamber), judgement of 20.11.2018, in case C-147/17, Sindicatul Familia, par.41; Judgment of 14.10.2010, Isère, C-428/09, cited, par. 28; CJEU, ( $5^{\text {th }}$ Chamber), Judgment of 21.02.2018, case C-518/15, Matzak, par.28 and 29, www.curia.eu; Judgment of 20.09.2007, Kiiski, C-116/06, EU:C:2007:536, par. 26 and the case-law cited there; Judgment of 1.12.2005, case C-14/04, Abdelkader Dellas, Confédération générale du travail, Fédération nationale des syndicats des services de santé et des services sociaux CFDT, Fédération nationale de l'action sociale Force ouvrière c. Premier ministre, Ministre des Affaires sociales, du Travail et de la Solidarité, ECLI:EU:C:2005:728, par. 44, and also the case-law cited there. 
under an individual labour contract and that of self-employed workers ${ }^{26}$.

\subsection{Criteria regarding the responsibility of organizing the activity}

The CJEU has been called to address this issue in an administrative case concerning the authorization of certain activities, being asked to determine whether an online platform through which public transport services are provided has the status of a public transportation service provider, with the consequence of being subject to specific authorization requests, or has the status of information service.

Although the issue of work relations between the on-line operator and service providers has not been addressed in this case, the decision sets out several principles that may be useful in determining whether an on-line platform can be considered as responsible for organizing the activity, or a simple intermediary between and customers and the service providers.

Thus, in Case C-434/1527, the Court held that "a brokerage service which, by means of an application for smart phones, has the purpose of linking, for the purpose of obtaining remuneration, unreachable drivers using their own vehicle with persons wishing to travel urbanely, must be regarded as being indissociably linked to a transport service and as falling within the scope of the qualification as a "transport service within the meaning of Article 58 (1) TFEU”.

In this case, the difference between information society services and classical services has been made.

The Court has identified the following elements defining the service provided as a transport service (par.37-39):
- the service is not limited to a brokerage service consisting of connecting, through a smartphone application, a non-professional driver using his own vehicle and a person wishing to make an urban journey;

- the provider of this brokerage service creates at the same time an offer of urban transport services which it makes accessible especially by means of computer tools such as the used application;

- the provider of this brokerage service organizes the general operation of the application in favour of persons wishing to make use of this offer;

- the intermediation service is based on the selection of non-professional drivers using their own motor vehicle to which this company supplies an application, in absence of which, on the one hand, those drivers are not in a position to provide transport services and, on the other hand, the person who wants to make an urban journey would not access the services of those drivers;

- the supplier of the service exercises a decisive influence over the conditions of service provided by those drivers, such as: the fact that it determines, by means of the application used, at least the maximum price per race; that the company collects that price from the customer and retain a part of it before paying the rest to the driver and that it exercises a certain control over the quality of the motor vehicles and their drivers, as well as the behaviour of the latter, which may lead, if necessary, to their exclusion.

Therefore, in order to determine whether it is an information society service within the meaning of Article 1 (1) (b) of Directive $2015 / 1535^{28}$ or a service providing direct benefits to consumers, it must first be ascertained whether this is only a brokerage

\footnotetext{
${ }^{26}$ Communication from the Commission to the European Parliament, the Council, the European Economic and Social Committee and the Committee of the Regions - A European agenda for the collaborative economy, cited, p. 12.

${ }^{27}$ CJEU (Grand Chamber), Judgement of 20 December 2017, EU: C: 2017:981, Asociación Profesional Elite Taxi vs. Uber Systems Spain SL, www.curia.eu.

${ }^{28}$ Former art. 1, par. 2 of Directive 98/34, referred by art. 2 (a) of Directive 2000/31.
} 
service. Such a service offers to the users, both consumers and physical service providers, a virtual meeting place in which demand and supply meet freely, and workers choose freely to carry out an activity and agree with the beneficiary on the remuneration requested, collecting the price directly or with minimal involvement of the platform that offers only an electronic payment system and retains a commission just for the money transfer service.

On the contrary, if through the on-line platform its operator exercises a certain level of control, manifested in providing the service on its own behalf, controlling the level of charges, collecting and distributing the remuneration to the providers of work, controlling the professional qualities of those, their behaviour, it should be considered as a classical service provider, who retains responsibility for organizing the activities.

\subsection{Criteria defining the status as worker of individuals who work through on-line platforms}

CJEU has had the opportunity to rule on a number of cases, including some concerning the interpretation of the provisions of Directive 2003/88, on the notion of worker in European Union law by laying down rules to determine whether a person performing the work has this status or not .

At the same time, the Court has also ruled on provisions defining concepts which exclude the status of worker, such as the notion of a service provider within the meaning of Directive 2006/123 or a commercial agent within the meaning of Directive 86/653 / EEC.

Thus, for a person who performs an activity involving the conclusion of contracts with service and product recipients, in order to be a commercial agent within the meaning of Article 1 (2) of Directive 86/653, the activity performed must be independent.

The Court has held ${ }^{29}$ in this regard that, in order to retain that status, this essential requirement must be fulfilled (paragraph 23); it further pointed out that the circumstance that the worker performs the activity on the principal's premises, alone, does not exclude the independent character of the work (par. 28, 32); however, if the worker's independence is impaired, he/she loses the status of a commercial agent, that happening by subordinating to the instructions of the principal and by the ways of carrying out the tasks performed (par.32), under the latter aspect, being possible to be relevant that the work is carried out from the headquarters of the principal. Thus, being in the immediate proximity of that principal, by virtue of his presence at his seat, that agent may be subject to the instructions of that principal and, at the same time, by having material advantages connected with that presence, such as the provision of a workspace or the access to the organizational facilities of that head office, it cannot be ruled out that the agent in question is in fact in a situation which prevents him from carrying out his activity independently from the point of view of organizing this activity or the associated economic risks (par.33).

Consequently, if those elements are fulfilled and the individual does not enjoy total independence, he/she can only have the status of worker, so that judgment is relevant in this respect.

The CJEU had the opportunity to analyse the notion of worker even in cases concerning the organization of working time.

The Court held that Directive 2003/88 did not refer either to Article 3 (a) of Directive 89/391 (which defines the concept

\footnotetext{
${ }^{29}$ CJEU, (4 ${ }^{\text {th }}$ Chamber), judgement of 21.11.2018, C-452/17, EU: C: 2018:935, in case Zako SPRL.
} 
of 'worker') or to the definition of a worker as is apparent from the legislation and /or national practices ${ }^{30}$ and, for the purposes of its application, that notion cannot be interpreted differently according to the national legal systems but has a specific autonomous meaning to Union law $^{31}$ and must not be interpreted restrictively ${ }^{32}$.

In the Court's view, the concept of a worker must be defined according to objective criteria characterizing the employment relationship, taking into account the rights and obligations of the persons involved ${ }^{33}$ and the sui generis legal nature of a labor relationship from the perspective of national law cannot have any effect on the status of worker within the meaning of Union $\operatorname{law}^{34}$. For example, the Court has held that the fact that a person who performs work is not subject to the Labour Code in his country of employment cannot be decisive for assessing the existence of an employment relationship between the parties, that generating a legal situation sui generis $^{35}$.

The CJEU also stated that it is for the national court to determine whether the applicant falls within the concept of a worker, in which case it must conclude based on objective criteria and assess in its entirety all the circumstances of the case before it, which are connected with the nature of both the activities in question and the relationship between the parties concerned $^{36}$. In that analysis, the national court must in particular verify whether the work actually provided by the person concerned can be regarded as normally belonging to the labor market, taking into account not only the status and practices of the beneficiary of the work concerned but also the purpose of the activity and the nature and the arrangements for the performance of work ${ }^{37}$.

The Court has held in many cases that an essential characteristic of the employment relationship is the fact that a person performs the work in return of remuneration for a certain period of time in favour of another person and under that

${ }^{30}$ CJEU (2 ${ }^{\text {nd }}$ Chamber) Judgment of 14.10 .2010 , case C-428/09, Isère, cited, par.27; CJEU, $1^{\text {st }}$ Chamber, Judgement of 26.03.2015, case C 316/13, Gérard Fenoll c. Centre d'aide par le travail „La Jouvene”, Association de parents et d'amis de personnes handicapées mentales (APEI) d'Avignon, ECLI:EU:C:2015:200, par.24, www.curia.eu.

${ }^{31}$ CJEU, Judgment of 14.10.2010, ${ }^{\text {nd }}$ Chamber, case C 428/09, cited, par.28; CJEU, $1^{\text {st } C h a m b e r, ~ J u d g e m e n t ~ o f ~}$ 26.03.03. 2015, case C 316/13, cited, par.25; CJEU, (5 ${ }^{\text {th }}$ Chamber), Judgment of 21.02.2018, in case C-518/15, Matzak, par.28, www.curia.eu.

${ }^{32}$ CJEU, $5^{\text {th }}$ Chamber, Ordinance of 7.04.2011, case C-519/09, Dieter May c. AOK Rheinland/Hamburg - Die Gesundheitskasse, ECLI:EU:C:2011:221, par.21, www.curia.eu.

${ }^{33}$ CJEU, Judgment of 14.10.2010, $2^{\text {nd }}$ Chamber, case C 428/09, cited, par.28; CJEU, $1^{\text {st }}$ Chamber, Judgement 26.03.2015, case C- 316/13, cited, par.27.

${ }^{34}$ CJEU, Judgment of 14.10.2010, $2^{\text {nd }}$ Chamber, case C 428/09, cited, par.30; see Judgment of 20.09.2007, Kiiski, C-116/06, Rep., p. I 7643, par. 26 and the case-law cited; CJEU, $1^{\text {st }}$ Chamber, Judgement of 26.03.2015, case C316/13, cited, par.31; Judgement Trojani, C-456/02, EU: C: 2004:488, par. 16; CJEU, (5 ${ }^{\text {th }}$ Chamber), Judgment of 21.02.2018, in case C-518/15, Matzak, par.29, www.curia.eu.

${ }^{35}$ CJEU, $1^{\text {st }}$ Chamber, Judgement of 26.03.2015, case C -316/13, cited, par.30.

${ }^{36}$ CJEU, Judgment of $14.10 .2010,2^{\text {nd }}$ Chamber, case C 428/09, cited, par.29; CJEU, $1^{\text {st }}$ Chamber, Judgement of 26.03.2015, case C 316/13, cited, par.29; Judgement Trojani, C 456/02, EU:C:2004:488, par. 17.

${ }^{37}$ CJEU, $1^{\text {st }}$ Chamber, Judgement of 26.03 . 2015, case C 316/13, cited, par.42; see mutatis mutandis, Judgement Trojani, C-456/02, EU: C: 2004:488, par. 24 (in this case, the question arises whether the applicant can claim a right of residence as an employed or self-employed person or a provider of services in the situation where work is done under a social-professional re-integration program run by a non-profit organization). 
person direction ${ }^{38}$. As a result, it has been shown that a 'worker' must be considered to be any person who carries out real and effective activities in order to obtain remuneration $^{39}$, except for activities which are so small that they appear to be purely marginal and accessories ${ }^{40}$. In this regard, it was appreciated that in the context of collaborative economy, when a person provides purely marginal or ancillary services using on-line platforms, this would indicate that that person does not have the status of worker while the provision of stable work leads to the qualification of that person either as a worker or as self employed according to the analysis of other facts ${ }^{41}$.

In the Court's view, neither the higher or lower productivity of the person concerned, nor the origin of the resources for remuneration, or the limited level of remuneration, can have consequences on the status of worker within the meaning of Union law ${ }^{42}$. Also, in the Court's view, the existence of an employment relationship is not excluded either by the overall reduced duration of the activity ${ }^{43}$ or the reduced duration of the daily activity ${ }^{44}$. Also, the CJEU has held that this status is not excluded by the fact that the worker enjoys a considerable margin of appreciation in the day-to-day exercise of his duties or that the mission attributed is a "trust mission" 45 .

In the recent case of Matzak, the CJEU also held ${ }^{46}$ that "any person who carries out real and effective work is to be regarded as a” worker “, except for activities that are so small that they appear to be purely marginal and accessories" and "the characteristic element defining a report of work consists in the fact that a person performs work in return for which he receives a remuneration, for a certain period of time, for another person and under his direction ${ }^{47}$.

In an earlier judgment, the Court has already held that must be regarded as a worker within the meaning of European Union law also a person who has concluded a contract on the basis of which she/he provides occasional work, on request and for irregular periods of time, being paid only for

\footnotetext{
${ }^{38}$ CJEU, Judgment of 14 .10. 2010, $2^{\text {nd }}$ Chamber, case C-428/09, cited, par.28; see mutatis mutandis, for article 39 CE, Judgment of 3.07.1986, Lawrie Blum, 66/85, Rec., p. 2121, par. 16 and 17, and also Judgment of 23 .03. 2004, Collins, C-138/02, Rec., p. I 2703, par. 26; CJEU, $5^{\text {th }}$ Chamber, Ordinance of 7.04.2011, case C 519/09, cited, par.21; see especially the Judgment of 3 .07. 1986, Lawrie Blum, 66/85, Rec., p. 2121, par. 16 and 17, Judgment of 23 .03. 2004, Collins, C- 138/02, Rec., p. I 2703, par. 26, and Judgment of 7.09.2004, Trojani, C-456/02, Rec., p. I 7573, par. 15; CJEU, $1^{\text {st }}$ Chamber, Judgement of 26.03.2015, case C 316/13, cited, par.27; Judgment of 20.09.2007, Kiiski, C 116/06, par.25; CJEU, ( $5^{\text {th }}$ Chamber), Judgment of 21.02.2018, in case C-518/15, Matzak, par.28, www.curia.eu.

${ }^{39}$ Judgement Trojani, C-456/02, EU:C:2004:488, par. 17.

${ }^{40}$ CJEU, $5^{\text {th }}$ Chamber, Ordinance of 7.04.2011, case C 519/09, cited, par.21; CJEU, $1^{\text {st }}$ Chamber, Judgement 26 .03. 2015, case C 316/13, cited, par.27; CJEU, (5th Chamber), Judgment of 21 .02. 2018, in case C-518/15, Matzak, par.28, www.curia.eu.

${ }^{41}$ Communication from the Commission to the European Parliament, the Council, the European Economic and Social Committee and the Committee of the Regions - A European agenda for the collaborative economy, cited, p. 14.

${ }^{42}$ CJEU, $1^{\text {st }}$ Chamber, Judgement 26.03.2015, case C 316/13, cited, par.34; see Judgement Bettray, 344/87, EU:C:1989:226, par. 15 and 16, Judgement Kurz, C-188/00, EU:C:2002:694, par. 32, and also Judgement Trojani, C 456/02, EU:C:2004:488, par. 16.

43 CJEU (Sixth Chamber), Judgment of 6 November 2003, in Case C-413/01, Franca Ninni-Orascheand Bundesminister für Wissenschaft, Verkehr und Kunst, par.25.

${ }^{44}$ CJEU, Judgment of 3 June 1986, in case C-139/85, R. H. Kempf v Staatssecretaris van Justitie, par.13.

${ }^{45}$ see for this opinion CJEU, Judgment of 10.09.2014, Haralambidis, C-270/13, EU:C:2014:2185, par. 39-41, and Judgment of 9.07.2015, Balkaya, C-229/14, EU:C:2015:455, par. 41.

${ }^{46}$ CJEU, (5th Chamber), Judgment of 21.02.2018, in case C-518/15, Matzak, www.curia.eu.

${ }^{47}$ For the same opinion see Judgment of 26 .03. 2015, Fenoll, C-316/13, EU:C:2015:200, par. 27 and the case law cited.
} 
the work actually done, and without any obligation for the employer to actually request the work ${ }^{48}$.

However, the Court held that, in order to determine whether the activity was real and not a purely marginal activity, the national court may have regard to the irregular nature and limited duration of the work actually performed, which may indicate that it is a marginal activity; it is very important, however, that the CJEU has held in this context that another important element in the analysis of national courts is whether the person concerned must remain at the disposal of the employer to perform the work if so requested ${ }^{49}$.

In a recent ruling ${ }^{50}$, the CJEU reiterated its previous jurisprudence on the elements defining the notion of worker. Accordingly, it follows from the case-law of the CJEU:

- the essential characteristic of the employment relationship is the fact that a person performs work in return for which she/he receives a remuneration in a given period for another person and under his direction $^{51}$;

- an employment relationship requires a relationship of subordination between the worker and his employer, but the existence of such a link must be assessed on a case-bycase basis in the light of all the elements and circumstances of the relationship between the parties ${ }^{52}$;

- the natural persons, in relation to the company with which they have contractual relations, are in a subordination relation materialized by the continuous supervision and evaluation of their activities by the respective company in relation to the requirements and the criteria specified in the contract, in order to carry out the activity ${ }^{53}$.

It should also be noted that the CJEU has analysed the issue of organizing working time, including in the case of an independent self-employed worker who was working on demand ${ }^{54}$. The applicant in the main proceedings did not work under an individual employment contract but had the status of self-employed, performing work according to a contract on the basis of which he was remunerated only by a commission for the work carried out, very similar to the situation of the persons supplying work based on orders received through an electronic platform. For this reason, the employer did not consider that it should grant him leave of absence and a leave allowance as to an employee on the basis of an employment contract. However, in its decision the Employment Tribunal considered that the applicant was to be classified as a 'worker' within the meaning of Directive 2003/88. It is true that in its judgment the CJEU did not consider whether or not the plaintiff in the main proceedings had the status of a worker within the meaning of Directive 2003/88, which is an autonomous concept of EU law. It can be argued that the CJEU has started from the

\footnotetext{
48 CJEU, Judgment of 26 February 1992, in case C-357/89, V. J. M. Raulin v Minister van Onderwijsen Wetenschappen, par.9.

49 CJEU, Judgment of 26 February 1992, in case C-357/89, V. J. M. Raulin v Minister van Onderwijsen Wetenschappen, par.14.

${ }^{50}$ CJEU (Grand Chamber), judgement of 20.11.2018, in case C-147/17, Sindicatul Familia.

51 CJEU, (Grand Chamber), judgement of 20.11.2018, in case C-147/17, Sindicatul Familia, cited, par.41; Judgment of 14.10.2010, Isère, C-428/09, cited, par. 28 and the case-law cited.

52 Judgment of 10.09.2015, Holterman Ferho Exploitatie and others, C-47/14, EU:C:2015:574, par. 46.

${ }^{53}$ CJEU (Grand Chamber), judgement of 20.11.2018, in case C-147/17, Sindicatul Familia, cited par.45.

${ }^{54}$ CJEU ( ( $^{\text {th }}$ Chamber), Judgment of 29.11.2017 în case C-214/16, Conley King vs. The Sash Window Workshop Ltd, Richard Dollar.
} 
presumption of the relevance of the reference for a preliminary ruling to the national court ${ }^{55}$, on the basis of the British court's conclusion that the applicant was a worker. However, it is noteworthy that the CJEU was in no way obliged to accept this conclusion and could have started the analysis of the referral with the verification of the applicability of Directive 2003/88 and of whether the situation of the applicant falls within its scope; the fact remains that the CJEU had no objection to the classification of the applicant as a worker within the meaning of Directive 2003/88 by the referring court ${ }^{56}$.

This judgment may be of great relevance in the future as a precedent in the classification of legal relationships between workers through an electronic order distribution platform and the owner of such a platform.

From the perspective of national law, there is the question of the qualification of the legal relations established between the parties, namely whether they are employment relationships or trade relations between professionals.

On this regard, there are already different solutions given by the EU courts on the basis of a case-by-case analysis. For example, given that workers using an electronic platform are registered as selfemployed, in some cases they were qualified as employees ${ }^{57}$ while in other cases they were considered not to have this status ${ }^{58}$. Recently, the bond of subordination, defining for the labour relation, was found in a situation where the on line application was equipped with a system of geolocation allowing the real-time monitoring by the company of the position of the courier and the accounting of the total number of kilometres travelled and, secondly, the company had power of sanction with respect to the courier ${ }^{59}$.

The Romanian High Court of Cassation and Justice - the Panel for preliminary clarification on legal aspects, by Decision no. 37 of November 7, 2016, found that in the event of a failure by the parties to conclude a written employment contract, the natural person who has worked for and under the authority of the other party has the possibility to ask the court to acknowledge the existence of the employment relationship and its effects even if the employment relationship ceased prior to the filing of the petition to the court.

In order to analyse the nature of legal relationships in the frame of which work is done, there may be relevant the provisions of art. 7 of Law no. 227/2015 on the Fiscal Code, defining independent and dependent activities as follows:

- dependent activity - any activity carried out by a natural person in an incomegenerating employment relationship;

- dependent activity on the main job any activity performed on the basis of an individual employment contract or a special legal status, declared to the employer as a main job by the employee; if the activity is carried out for several employers, the employee is obliged to declare only to the chosen employer that the place in question is the place where he performs the function

\footnotetext{
55 See for example CJEU- Judgment of 6.09.2016, in case C-182/15, EU:C:2016:630, par. 20 and the case-law cited there.

56 Răzvan Anghel - Working time and rest time in recent CJEU case law (July 2017 - February 2018), Revista EuRoQuod no.2/2018, pp. 77-78.

57 United Kingdom Employment Appeal Tribunal London, [2018] IRLR 97, [2017] UKEAT 0056_17_1011, [2018] ICR 453, [2017] WLR (D) 809, par.124, available: www.bailii.org, accessed 18.04.2018.

58 Among others, Conseil de Prud'hommes de Paris, $n^{\circ}$ RG: F 16/11460, sentence of 29.01.2018.

59 Cassation Court, Social Chamber, Public audience of Wednesday, 28 November 2018, no.: 17-20079, www.legifrance.gouv.fr.
} 
he/she considers to be the main job;

- self-employment - any activity carried out by a natural person for the purpose of obtaining income, which meets at least 4 of the following criteria:

- the individual has the freedom to choose the place and way of working, as well as the work schedule;

- the individual has the freedom to work for more than one client;

- the risks inherent in the activity are assumed by the natural person carrying out the activity;

- the activity is done by using the patrimony of the natural person who performs it;

- the activity is performed by the individual by using the intellectual capacity and / or the physical performance of the person, depending on the specificity of the activity;

- the natural person is part of a professional body / order with the role of representing, regulating and supervising the profession, according to the special normative acts regulating the organization and the exercise of the respective profession;

- the natural person has the freedom to carry out the activity directly, with employed person or through collaboration with third parties under the law.

Thus, when the activity does not meet the criteria to be qualified as independent, the income obtained is qualified by the Fiscal Code as salary income and assimilated to salaries precisely to eliminate the possibility of dissimulation of employment relationships in selfemployment.

Per a contrario, if there are not met at least four of the criteria set out in Art. 7 of Fiscal Code, the activity cannot be considered as independent, so that it can be considered that in fact the activity was performed in an employment relationship even without the conclusion of an individual contract of employment in written form.

Therefore, it could be considered as elements which, once proven, would lead to the conclusion that a work relationship exists, among others, the following:

- the individual does not have the freedom to choose the place and the way of doing the work, as well as the work schedule, as established by the beneficiary's indications;

- the risks inherent in the activity are assumed by the person benefiting from the activity;

- the activity is done by using the beneficiary's goods;

- the natural person does not have the freedom to carry out the activity directly, with employed personnel or through collaboration with third parties under the law $^{60}$.

\section{The practical difficulties of delimiting working time from rest time in the collaborative economy}

With regard to the delimitation of working time from rest time for individuals who work in other areas than those belonging to the employer, the CJEU offered a solution, pointing out that "it is up to the employer to use the necessary control tools to avoid possible abuses" of employees who

\footnotetext{
${ }^{60}$ Răzvan Anghel, Procedura soluţionării conflictelor individuale de muncă - Ghid pentru practicieni, Ediţia a II-a, revizuită şi adăugită, C.H. Beck Publishing House, Bucharest, 2018, pp. 308-309.
} 
work outside their premises ${ }^{61}$, such as the use of credit cards dedicated exclusively to the payment of fuel needed for the professional use of vehicles made available by the employer ${ }^{62}$.

In the French case-law, for example, it has been held in several cases that a worker's geolocation system, which has a certain freedom in the organization of work, can be used by the employer to determine the working time but only if there is no other means of that control to be carried out and only if the employee and the competent administrative authority are informed, since the rights and freedoms of the employee can only be affected if the measure is justified by the aim pursued and proportionate to $i^{63}$, so that another solution was even in the sense that such a measure it is not justified in the particular case of such an employee ${ }^{64}$.

In the situation where the working time can no longer be delimited by reference to the time a worker is at the workplace determined by the employer, the work being done anywhere and at any time, it becomes relevant the actual performance of the work so that the durations of the work itself must be clearly determined. For this purpose, electronic means of monitoring the employee activity can be used, ranging from cameras and systems to monitor access to a work area or to monitor the energy consumption of some equipment and continuing with the means of modern information technology such as internet traffic monitoring, computer keyboard monitoring, replication of desktop activity, verification of information that reflects software activity, electronic communications control, social networking activities, geolocation systems, dedicated software monitoring the activity of mobile devices, and so on ${ }^{65}$. Employers may wish to use these technical means to control the employee's behaviour and thus to be able to delimit working time from rest time ${ }^{66}$ in order to determine remuneration and to verify employee compliance with service obligations.

Using these means of remote monitoring and control of employees' work poses, however, serious and numerous issues concerning the protection of employees' personal data, the protection of their privacy and dignity, especially in the context where the traditional and clear limit between working time and personal time is becoming more blurred with the development of flexible forms of work organization $^{67}$.

It is important that CJEU has already established that a record of working time which implies the indication of the hours at which each worker begins and ends the working day, as well as the interruptions or appropriate breaks, is part of the concept of

\footnotetext{
${ }^{61}$ CJEU, $3^{\text {rd }}$ Chamber, Case C-266/14, Judgment of 10.09.2015, Federación de Servicios Privados del sindicato Comisiones obreras (CC.OO.) c. Tyco Integrated Security SL, Tyco Integrated Fire \& Security Corporation Servicios SA, ECLI:EU:C:2015:578, par. 40 (www.curia.eu).

62 Idem, par. 41.

63 „Cassation Court, Social Chamber, Public audience of Wednesday, 03 November 2011, no.: 10-18036, www.legifrance.gouv.fr.

64 Cassation Court, Social Chamber, Public audience of Wednesday, 17 December 2014, no.: 13-23645, ECLI:FR:CCASS:2014:SO02387, www.legifrance.gouv.fr.

${ }^{65}$ Răzvan Anghel - Noua reglementare privind telemunca..., cited, p. 215.

${ }^{66}$ See also A. Fabre, Le temps de trajet des travailleurs nomads devant la Cour de justice: la mobilité vue de plus haut, Droit Social 1/2016, p. 61 (https://search.proquest.com/openview/93c636846dc716af2978ca28f35137c5/1).

${ }^{67}$ T.A. Coelho Moreira, The electronic control of the employer in Portugal, in Labour \& Law Issues, vol. 2, no. 1/2016, p. i.4.
} 
"personal data" in the meaning of art.2 (a) of Directive 95/46 / EC $^{68}$.

Next, however, the question is whether the period of availability, in which the employee does not actually work but only awaits the orders of the employer or the orders of its clients to carry out certain activities, must be considered working time.

The problem arises in the context in which the CJEU has determined that the availability time should be considered as working time only when the worker is present in the workplace or in another place imposed by the employer ${ }^{69}$, but not when at his/her own home ${ }^{70}$ or in another location not set by the employer ${ }^{71}$ unless the way in which the activity is organized makes it impossible for them to devote themselves to their own activities ${ }^{72}$.

As a result, new elements for delimiting working time from rest time must be identified for workers in the collaborative economy, where working time is no longer defined by the presence in a certain space.

For example, a British appeal court has determined that the working time of employees using an online order platform for potential clients can be determined by reference to the time the application provided by the employer is active, which means that the employee is at his disposal to take orders ${ }^{73}$.

However, availability time differs in its qualities depending on the type of activity and on-line platform. If work on demand in a given location may involve periods of availability in which the worker cannot devote himself to other activities, crowdwork, which allows more freedom in choosing tasks to be performed and the moment of fulfilment, may imply that periods of waiting for a new task does not constitute real periods of availability but rest periods that do not constitute working time.

At the same time, provisions on the protection of personal data may prevent the use of means of supervising the activity of the employee if they interfere with his private life in the context in which he carries out the work including in private premises belonging to him and during periods of time which are interspersed with periods affected by private interests. This also creates a further difficulty in determining working time, which affects mainly the worker who finds himself faced with a very difficult choice: to renounce the protection of privacy or to renounce the protection of health and safety at work by limiting working time in relation to the employer.

\section{Conclusions}

The new ways of labour supply in the collaborative economy rise primarily the question of the status of the individual that do the work, whether he/she is a worker or a self-employed worker, essential being the verification of the fulfilment of the condition of subordination, which has several defining elements: the one who performs the work

\footnotetext{
${ }^{68}$ CJEU, $3^{\text {rd }}$ Chamber, Case C-342/12, Judgment of 30.05.2013, Worten - Equipamentos para o Lar SA c. Autoridade para as Condições de Trabalho (ACT), ECLI:EU:C:2013:355 (www.curia.eu).

${ }^{69}$ For example, CJEU ( $5^{\text {th }}$ Chamber $)$ - Ordinance of 11.01 .2007 in case C 437/05, Jan Vorelvs. Nemocnice Český Krumlov, EU:C:2007:23.

${ }^{70}$ CJEU, Judgement of 03.10.2000 in case C-303/98, Sindicato de Médicos de Asistencia Pública (SIMAP) c. Conselleria de Sanidad y Consumo de la Generalidad Valenciana, EU:C:2000:528.

${ }^{71}$ CJEU (4 ${ }^{\text {th }}$ Chamber) Judgement in case C-87/14, European Comission vs. Ireland, EU:C:2015:449.

72 CJEU, ( $5^{\text {th }}$ Chamber), Judgment of 21 .02. 2018, in case C-518/15, Matzak, cited.

${ }^{73}$ United Kingdom Employment Appeal Tribunal London, 2018, IRLR 97, 2017, UKEAT 0056_17_1011, 2018, ICR 453, 2017, WLR(D) 809, par. 124 (www.bailii.org) accessed 18.04.2018.
} 
must act under the leadership of the on-line platform, which determines the nature of the activity, the remuneration and the working conditions $^{74}$; any activity performed outside a relationship of subordination from the point of view of working and remuneration conditions must be regarded as a selfemployed activity for which the individual is solely responsible ${ }^{75}$. At the same time, the activity must be a consistent one to define a working relationship and not at such a low level as to be purely marginal and auxiliary precisely because in the collaborative economy, many people provide occasional, isolated activities for additional nonessential income.

The spatialization of work and the determination of working time by reference to the duration of the worker's presence in an area imposed by the employer in the exercise of his prerogative of controlling and disciplining the work has generated in the jurisprudence, including the case-law of the CJEU, the concern to find criteria for delimitation of working time from rest time by reference to the space.

In this context, without removing from the definition of working time the periods in which the worker actually carries out the work, the CJEU has established criteria for delimiting working time from rest time by reference to the presence of worker to the work place in order to include inactive periods when the worker is at the employer disposal, exercising the duties of work so that the Court was not asked with preliminary questions concerning the delimitation of working time by the rest time, according to the criterion of actual work, as in the classical way of work organization the employer supervision and control was presumed to be exercised so no problems of determining the actual time of work were of interest.

In the context of the new way of organizing work, mainly results-oriented, abandoning the employer's constant supervision and of work despatialization, the CJEU's case law no longer provides clear rules for the delimitation of working time by rest time, especially as regards inactive availability periods, but only principles and hints for future possible solutions.

Practically, if a worker is awaiting orders from the employer, in a freely chosen place, according to CJEU's case law, that period should not be considered working time. But if the period of actual work performance cannot be determined, although obviously the work has been done, the interpretation should be in favour of the employee, presumed to be in a vulnerable position, so that the entire period of availability to be considered as working time especially that, according to the case-law of the CJEU, the qualification of a period as working time does not depend on the intensity of work $^{76}$ and there is no intermediate category between working time and rest time so that if a period cannot be considered rest time it must automatically be considered working time, as the two notions are mutually exclusive ${ }^{77}$. To assess whether a period is rest time, all the specific elements

\footnotetext{
${ }^{74}$ Communication from the Commission to the European Parliament, the Council, the European Economic and Social Committee and the Committee of the Regions - A European agenda for the collaborative economy, cited, p. 13.

75 CJEU, Judgment of 20 November 2001, in case C-268/99, Aldona Malgorzata Jany and Othersand Staatssecretaris van Justitie, www.curia.eu, accessed 13.03.2019, par.33, 34, 37.

${ }^{76}$ CJEU, Judgment of 1.12.2005, case C-14/04, Dellas, cited, par.43 and 58 of the judgement.

77 CJEU, Judgement of 3.10.2000, in case C-303/98, SIMAP, cited, par.47, CJEU, $2^{\text {nd }}$ Chamber, Judgment of 1.12.2005, case C-14/04, Dellas, cited, par.43, www.curia.eu; CJCE, $5^{\text {th }}$ Chamber , Ordinance of 11.01.2007, case C-437/05, Jan Vorel c. Nemocnice Český Krumlov, ECLI:EU:C:2007:23, www.curia.eu, par.25; CJEU, 6 ${ }^{\text {th }}$ Chamber, Ordinance of 4.03.2011, case C 258/10, Nicuşor Grigore c. Regiei Naţionale a Pădurilor Romsilva -
} 
of the activity must be analysed, especially if the worker must be in a certain area to respond to the orders and whether she/he is under the obligation to start work shortly after receiving the order ${ }^{78}$.

Such an interpretation is able to determine employers to adopt effective means of quantifying the working time, which is such as to ensure adequate protection for workers.

Furthermore, the fact remains that Article 17 (1) of Directive 2003/88 allows Member States to derogate from Articles 3 to 6,8 and 16 where, based on the specific characteristics of the activity pursued, the length of working time is not measured and predetermined or can be determined by the workers themselves.

However, these exemptions must be adopted by states through normative acts, as the provision in the directive is not enough ${ }^{79}$. Although it cannot derogate from the provisions of Article 2 which include the definition of working time, the derogation from the provisions of Article 6 on maximum weekly working time makes it useless to delimit working time from rest time as this is relevant only for limitations of working time.

The new forms of working in the collaborative economy will further pose many problems on working time organization and regarding the delimitation of it from rest time.

The analysis on whether working time regulations are applicable and how will have to be done on a case by case approach, depending of the particular and ever changing conditions of work imposed by the on-line platforms, even in the case of the same platform if the terms and conditions of use are changed.

From the CJEU previous case law some principles may be detached for finding the legal solution to working time problems, generated by innovative work arrangements, as those questions were not addressed in a preliminary question on the subject, and such a possible future answer, anyway may not be applicable to all the possible situations. All those principles are useful on the condition to find first the essence of every work arrangement in the collaborative economy and then find the applicable principle.

\section{References}

- Aloisi, A. - Commoditized workers: Case study research on labor law issues arising from a set of on-demand/gig economy platforms, Comp. Lab. L. \&Pol'y J. 37/2015.

- Aloisi, A. - Il lavoro „a chiamata” e le piattaforme online della collaborative economy: nozioni e tipi in cerca di tutele, Labour \& Law issues, nr. 2/2016.

- Anghel, R. - Noua reglementare privind telemunca. Probleme specific privind delimitarea timpului de lucru de timpul de odihnă în cazul telesalariaţilor, Curierul Judiciar, nr. 4/2018.

- $\quad$ Anghel, R. - Working time and rest time in recent CJEU case law (July 2017 February 2018), Revista EuRoQuod nr.2/2018.

\footnotetext{
Direcţia Silvică Bucureşti, ECLI:EU:C:2011:122, www.curia.eu, par.43; CJEU, $3^{\text {rd }}$ Chamber, Judgment of 10.09. 2015, case C 266/14, Tyco, cited, par.26.

${ }^{78}$ Mutatis mutandis CJEU, (5 ${ }^{\text {th }}$ Chamber), Judgment of 21.02.2018, in case C-518/15, Matzak, cited.

${ }^{79}$ CJEU, (2 ${ }^{\text {nd }}$ Chamber) Judgement of 21.10.2010 in case C-227/09, Antonino Accardoe v.Comune di Torino, par.46 and 51, www.curia.eu.
} 
- Anghel, R.-Procedura soluţionării conflictelor individuale de muncă - Ghid pentru practicieni, Ediţia a II-a, revizuită şi adăugită, C.H. Beck Publishing House, Bucharest 2018.

- Berg, J., Furrer, M., Harmon, E., Rani, U., Silberman, M.S. - Digital labour platforms and the future of work - Toward decent work in the online world, International Labour Organization, 2018;

- Bogg, A.-Foster parents and fundamental labour rights, www.uklabourlawblog.com, 25.07.2018.

- Bouffartigue, P.,Bouteiller, J.-A propos des normes du temps de travail, Revue de l'IRES no. 42/2003, 2.

- Boulin, J.-Y. ,Cette, G., Taddéi, D.-Le temps de travail: une mutation majeure, Futuribles 5/1992.

- Boulin, J.-Y. -Working time in the new social and economic context, Transfer: European Review of Labour and Research 7.2/2001.

- CJEU ( $5^{\text {th }}$ Chamber $)$ - Ordinance of 11.01 .2007 in case C- 437/05, Jan Vorel vs. Nemocnice Český Krumlov, EU:C:2007:23.

- CJEU ( $2^{\text {nd }}$ Chamber) Judgment of 14.10 .2010 , case C $-428 / 09$, Union syndicale Solidaires Isère c. Premier ministre, Ministère du Travail, des Relations sociales, de la Famille, de la Solidarité et de la Ville, Ministère de la Santé et des Sports, ECLI:EU:C:2010:612, www.curia.eu.

- CJEU (4 ${ }^{\text {th }}$ Chamber) Judgement in case C-87/14, European Commission vs. Ireland, EU:C:2015:449.

- CJEU (5th Chamber), Judgment of 29 .11. 2017 în case C-214/16, Conley King vs. The Sash Window Workshop Ltd, Richard Dollar.

- CJEU (Grand Chamber), Judgement of 20 december 2017, EU:C:2017:981, Asociación Profesional Elite Taxi vs. Uber Systems Spain SL, www.curia.eu.

- CJEU (Grand Chamber), judgement of 20.11.2018, in case C-147/17, Sindicatul Familia.

- CJEU (Sixth Chamber), Judgment of 6 November 2003, in Case C-413/01, Franca Ninni-Orascheand Bundesminister für Wissenschaft, Verkehr und Kunst.

- CJEU, Judgment of 10 .09. 2014, Haralambidis, C-270/13, EU:C:2014:2185.

- CJEU, Judgment of 23 .03. 2004, Collins, C- 138/02, Rec., p. I 2703.

- CJEU, Judgment of 3.07.1986, Lawrie Blum, 66/85, Rec., p. 2121.

- CJEU- Judgment of 6 .09. 2016, in case C-182/15, EU:C:2016:630.

- CJEU, Judgment of 5.10.2004, Pfeiffer e.a., C-397/01-C-403/01, Rec., p. I-8835,www.curia.eu.

- CJEU, (2 ${ }^{\text {nd }}$ Chamber) Judgement of 21.10.2010 in case C-227/09, Antonino Accardoe v. Comune di Torino, www.curia.eu.

- $\quad$ CJEU, ( $4^{\text {th }}$ Chamber $)$, judgement of 21.11.2018, C-452/17, EU:C:2018:935, in case Zako SPRL.

- CJEU, (5 $5^{\text {th }}$ Chamber), Judgment of 21.02.2018, in case C-518/15, Matzak, www.curia.eu.

- CJEU, $1^{\text {st }}$ Chamber, Judgement of 26.03.2015, case C 316/13, Gérard Fenoll c. Centre d'aide par le travail „La Jouvene”, Association de parents et d'amis de personnes handicapées mentales (APEI) d'Avignon, ECLI:EU:C:2015:200, www.curia.eu.

- CJEU, $2^{\text {nd }}$ Chamber, Judgment of 1 .12. 2005, case C-14/04, Abdelkader Dellas, Confédération générale du travail, Fédération nationale des syndicats des services de santé et des services sociaux CFDT, Fédération nationale de l'action sociale Force ouvrière c. Premier ministre, Ministre des Affaires sociales, du Travail et de la Solidarité, ECLI:EU:C:2005:728, www.curia.eu. 
- CJEU, $3^{\text {rd }}$ Chamber, Case C-266/14, Judgment of 10 .09. 2015, Federación de Servicios Privados del sindicatoComisionesobreras (CC.OO.) c. Tyco Integrated Security SL, Tyco Integrated Fire \& Security Corporation Servicios SA, ECLI:EU:C:2015:578 (www.curia.eu).

- CJEU, $3^{\text {rd }}$ Chamber, Case C-342/12, Judgment of 30 .05. 2013, Worten Equipamentos para o Lar SA c. Autoridade para as Condições de Trabalho (ACT), ECLI:EU:C:2013:355 (www.curia.eu).

- CJEU, $5^{\text {th }}$ Chamber, Ordinance of 7.04.2011, case C-519/09, Dieter May c. AOK Rheinland/Hamburg - Die Gesundheitskasse, ECLI:EU:C:2011:221, www.curia.eu.

- $\quad$ CJEU, $6^{\text {th }}$ Chamber, Ordinance of 4 .03. 2011, case C- 258/10, Nicuşor Grigore c. Regiei Naţionale a Pădurilor Romsilva - Direcţia Silvică Bucharest, ECLI:EU:C:2011:122, www.curia.eu.

- CJEU, judgement Bettray, C-344/87, EU:C:1989:226.

- CJEU, Judgement Kurz, C- 188/00, EU:C:2002:694.

- CJEU, Judgement of 3.10.2000 in case C-303/98, Sindicato de Médicos de Asistencia Pública (SIMAP) c. Conselleria de Sanidad y Consumo de la Generalidad Valenciana, EU:C:2000:528.

- CJEU, Judgment of 26 February 1992, in case C-357/89, V. J. M. Raulin v Minister van Onderwijsen Wetenschappen.

- CJEU, Judgment of 10 .09. 2015, Holterman Ferho Exploitatie and others, C-47/14, EU:C:2015:574.

- CJEU, Judgment of 20 November 2001, in case C-268/99, Aldona Malgorzata Jany and Othersand Staatssecretaris van Justitie, www.curia.eu;

- CJEU, Judgment of 20.09.2007, Kiiski, C-116/06, Rep., p. I 7643.

- CJEU, Judgment of 3 June 1986, in case C-139/85, R. H. Kempf v Staatssecretaris van Justitie.

- $\quad$ CJEU, Judgment of 7 .09. 2004, Trojani, C 456/02, Rec., p. I 7573.

- CJEU, Judgment of 9 .07. 2015, Balkaya, C-229/14, EU:C:2015:455.

- Coelho Moreira, T.A. -The electronic control of the employer in Portugal, in Labour \& Law Issues, vol. 2, nr. 1/2016.

- Cohen, B.,Kietzmann, J. - Ride on! Mobility business models for the sharing economy, Organization \& Environment 27.3/2014;

- Conseil de Prud'hommes de paris, no. RG: F 16/11460, judgement of 29.01.2018;

- Cassation Court, Social Chamber, Public audience of Wednesday, 03 November 2011, no.: 10-18036, www.legifrance.gouv.fr.

- Cassation Court, Social Chamber, Public audience of Wednesday, 17 December 2014, no.: 13-23645, ECLI:FR:CCASS:2014:SO02387,www.legifrance.gouv.fr.

- Cassation Court, Social Chamber, Public audience of Wednesday, 28 November 2018, no.: 17-20079, www.legifrance.gouv.fr.

- Dagnino, E. -Il lavoro nella on-demand economy: esigenze di tutela e prospettive regulatorie, Labour \& Law issues, nr. 2/2015.

- $\quad$ Donini, A.-Il lavoro digitale su piattaforma, Labour \& Law issues, no. 1/2015.

- EUROFOUND - Work on demand: Recurrence, effects and challenges, Publications Office of the European Union, Luxembourg, 2018.

- EUROFOUND, Employment and working conditions of selected types of platform work, Publications Offices of the European Union, Luxemburg, 2018.

- European Commission - Communication from the Commission to the European Parliament, the Council, the European Economic and Social Committee and the Committee of the Regions - A European agenda for the collaborative economy, Brussels, 2.6.2016 COM (2016) 356 final, 
https://ec.europa.eu/transparency/regdoc/rep/1/2016/EN/1-2016-356-EN-F11.PDF, p.3, accesed on 13.03.2019.

- $\quad$ Fabre, A.-Le temps de trajet des travailleurs nomads devant la Cour de justice: la mobilité vue de plus haut, Droit Social 1/2016.

- Friedman, G.-Workers without employers: shadow corporations and the rise of the gig economy, Review of Keynesian Economics 2.2/2014.

- Hamari, J., Sjöklint, M., Ukkonen, A. -The sharing economy: Why people participate in collaborative consumption, Journal of the Association for Information Science and Technology 67.9/2016.

- Heinrichs, H.-Sharing economy: a potential new pathway to sustainability, GAIAEcological Perspectives for Science and Society 22.4/2013;

- Messenger, J. - Working time and the future of work, International Labour Organization, ILO Future of Work Research Paper Series, 2018.

- Messenger, J.,Gschwind, L. - Three Generations of Telework, Conference paper $17^{\text {th }}$ ILERA World Congress, 7-11.09.2015, Cape Town, South Africa, disponibilă la https://www.ilera2015.com/dynamic/full/IL156.pdf (accessed 13.03.2019).

- Moarcăş, C.A. Impactul globalizării asupra reglementărilor din domeniul muncii. Posibile schimbări în sistemul relaţiilor industriale, Public Law Review, nr.1/2005.

- Rubery, J.- Working time in the UK, Transfer: European Review of Labour and Research 4.4/1998, p. 672.

- $\quad$ Rubery, J., Ward, K., Grimshaw, D., Beynon, H.-Working time, industrial relations and the employment relationship, Time \& Society 14(1)/2005.

- Schor, J. - Debating the Sharing Economy, Journal of Self-Governance \& Management Economics 4.3/2016.

- Seifert,H.-Flexibility through working time accounts: reconciling economic efficiency and individual time requirements, WSI-Diskussionspapiere, no. 130/2004.

- Supiot, A.-Temps de travail: pour une concordance des temps, Droit social, 1995;

- United Kingdom Employment Appeal Tribunal London, [2018] IRLR 97, [2017] UKEAT 0056_17_1011, [2018] ICR 453, [2017] WLR(D) 809, par.124, www.bailii.org, accessed 18.04.2018. 